\title{
Land-Use Leakage
}

KV Calvin

J Edmonds,

LE Clarke

Ben Bond-Lamberty
SH Kim

MA Wise

AM Thomson

P Kyle

December 2009

Pacific Northwest

NATIONAL LABORATORY 


\title{
DISCLAIMER
}

This report was prepared as an account of work sponsored by an agency of the United States Government. Neither the United States Government nor any agency thereof, nor Battelle Memorial Institute, nor any of their employees, makes any warranty, express or implied, or assumes any legal liability or responsibility for the accuracy, completeness, or usefulness of any information, apparatus, product, or process disclosed, or represents that its use would not infringe privately owned rights. Reference herein to any specific commercial product, process, or service by trade name, trademark, manufacturer, or otherwise does not necessarily constitute or imply its endorsement, recommendation, or favoring by the United States Government or any agency thereof, or Battelle Memorial Institute. The views and opinions of authors expressed herein do not necessarily state or reflect those of the United States Government or any agency thereof.

\author{
PACIFIC NORTHWEST NATIONAL LABORATORY \\ operated by \\ BATTELLE \\ for the \\ UNITED STATES DEPARTMENT OF ENERGY \\ under Contract DE-AC05-76RL01830
}

Printed in the United States of America
Available to DOE and DOE contractors from the Office of Scientific and Technical Information,
P.O. Box 62, Oak Ridge, TN 37831-0062;
ph: (865) 576-8401
fax: $(865)$ 576-5728
email: reports@adonis.osti.gov

\begin{abstract}
Available to the public from the National Technical Information Service, U.S. Department of Commerce, 5285 Port Royal Rd., Springfield, VA 22161 ph: (800) 553-6847 fax: $(703) 605-6900$ email: orders@ntis.fedworld.gov online ordering: http://www.ntis.gov/ordering.htm
\end{abstract}

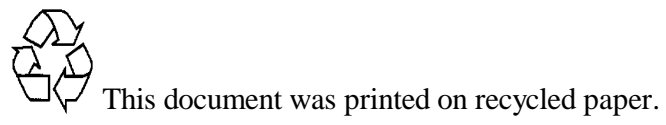




\title{
Land-use Leakage
}

Katherine Calvin, Jae Edmonds, Ben Bond-Lamberty, Leon Clarke, Sonny Kim, Page Kyle, Allison Thomson, Marshall Wise

\begin{abstract}
Leakage occurs whenever actions to mitigate greenhouse gas emissions in one part of the world unleash countervailing forces elsewhere in the world so that reductions in total global emissions are smaller than reductions in the mitigating regions alone. While many researchers have examined the concept of industrial leakage, leakage can also occur in the terrestrial system. We show that land-use leakage is potentially as large as or larger than industrial leakage. We identify two potential land-use leakage drivers, land-use policies and bioenergy, and run numerical experiments for each. We also show that the land-use policy environment exerts a powerful influence on leakage. International net terrestrial mitigation is a potential mechanism to extend emissions mitigation beyond the borders of emissions mitigating regions, but in a stabilization regime designed to limit radiative forcing to $3.7 \mathrm{~W} / \mathrm{m}^{2}$, this also implies greater emissions mitigation commitments on the part of mitigating regions.
\end{abstract}

\section{Introduction}

The issue of carbon emissions "leakage" has been a staple of analysis since the United Nations Framework Convention on Climate Change (UNFCCC; United Nations, 1992), which created the concept of "common but differentiated responsibilities." The entrance of the UNFCCC and the subsequent Kyoto Protocol created a world divided into parties with explicit limits on national emissions and those without. The concept of "land-use leakage" was identified by the Intergovernmental Panel on Climate Change (IPCC) in 2000 (Watson et al., 2000). The IPCC recognized that the introduction of land use policies in one region and time may affect land use in another region and time. However, there have been relatively few studies that attempt to quantify the magnitude and distribution of this leakage. One exception is Murray et al. (2004), who look at leakage effects in the global timber market and in a US-only agriculture and forestry simulation model.

Instead, the principal focus of the "leakage" literature in the modeling community to date has been "industrial" carbon leakage, which occurs when limits on carbon emissions from 
industrial activities in one region leads to the migration of those activities and their associated emissions to other regions without emissions limitations. As a consequence, global emissions mitigation is smaller than emissions mitigation in the region restricting its emissions, with the difference being a quantitative measure of the total system leakage. See for example studies by Felder and Rutherford (1993), Bollen et al., (2000), Burniaux and Oliveira Martins (2000), Paltsev (2001), Kuik and Gerlagh (2003), Babiker (2005) and Reinaud (2008).

Carbon emissions leakage occurs because carbon price differentials are established between emissions-control regions and the rest of the world. These carbon price differentials create incentives to move emissions-generating activities from expensive locations, i.e. the emissions control regions, to less expensive locations, i.e. regions without emissions controls, with larger price differentials creating greater pressures for leakage. A variety of mechanisms facilitate industrial leakage, including reductions in the world market prices of fossil fuels, the substitution of fossil fuels for non-fossil fuels in non-control regions, and shifts in the global distribution and allocation of investment capital. These are discussed and quantified in Calvin et al. (2009b).

While considerable attention has been paid to industrial carbon emissions leakage, little attention has been paid to the potential for land-use policies designed to enhance domestic emissions mitigation to drive leakage. In this paper, we take up the issue of "land-use leakage" and examine two potential mechanisms that could generate it: 1 . Terrestrial carbon policies to expand carbon storage on land in emissions control regions and 2. Indirect land use change emissions associated with the production of bioenergy feedstocks.

We will show that land-use leakage is related to, but different than indirect land-use change (ILUC). The former occurs whenever activities to reduce emissions in one region result 
in lesser reductions in global emissions. The core concept is the difference between emissions mitigation in one region and the rest of the world. Leakage can only occur in a world with heterogeneous emissions limitation policies. In contrast ILUC occurs whenever an activity to reduce emissions indirectly results in an increase in land-use emissions. The latter concept does not distinguish whether or not the indirect land-use change emission occurs within a single region or country, or between distinct regions or countries. In other words it is possible to have ILUC without leakage.

In exploring the phenomenon of land-use leakage we build on the work of Edmonds et al. (2008) and Wise et al. (2009a,b) in the context of scenarios developed by the EMF22 International Transition Scenario Subgroup (Clarke et al., 2009). This paper explores the concept of land-use leakage through a series of numerical experiments that employ the Global Change Assessment Model (GCAM), an integrated assessment model developed at the Joint Global Change Research Institute (JGCRI) that builds on the foundations established in the JGCRI MiniCAM modeling framework.

We show that land-use leakage depends on the policy environment. We identify several policy environments in which land-use leakage can arise and several environments in which it does not arise. We further show that circumstances in which rates of land-use leakage could exceed those associated with industrial leakage. Section 2 describes the model used for this study. Section 3 presents the reference scenario, used as a point of departure for the analysis. In Section 4, we describe the EMF 22 study and our implementation of it. Section 5 introduces the concept of land-use leakage and the two potential drivers of it. Section 6 presents results isolating the effect of terrestrial policy on leakage. Section 7 looks at the role of bioenergy in land-use leakage. Section 8 provides some concluding thoughts. 


\section{The GCAM Model}

The analysis in this paper uses the Global Change Assessment Model (GCAM). GCAM is an integrated assessment model built on the foundations of MiniCAM (Kim et al., 2006, Clarke, et al., 2007b, Brenkert et al. 2003). GCAM is a dynamic-recursive model, which links a global energy-economy-agricultural-land-use model with a suite of coupled gas-cycle, climate, and icemelt models integrated in the Model for the Assessment of Greenhouse-Gas Induced Climate Change (MAGICC). GCAM tracks emissions and concentrations of greenhouse gases and shortlived species. ${ }^{1}$ The GCAM is a descendent of a model developed by Edmonds and Reilly (1985). It has been used extensively for energy, climate, and other environmental analyses conducted for organizations that include the U.S. Department of Energy (DOE), the U.S. Environmental Protection Agency, the Intergovernmental Panel on Climate Change (IPCC), and other government, private and non-governmental organizations. Documentation for GCAM can be found at http://www.globalchange.umd.edu/models/MiniCAM.pdf/.

The GCAM energy-economy-land-use-land-cover representation is a dynamic recursive economic model. It is driven by assumptions about population size and labor productivity that determine potential gross domestic product in each of 14 regions. GCAM is solved on a 15-year time step and is used to assess potential future developments to the year 2095. GCAM establishes market-clearing prices for all energy, agriculture and land markets such that supplies and demands for all markets balance simultaneously. That is, there are no excess supplies or demands for land, agricultural products, primary energy, final energy, or energy services.

\footnotetext{
${ }^{1}$ GCAM tracks emissions of 15 greenhouse related gases: $\mathrm{CO}_{2}, \mathrm{CH}_{4}, \mathrm{~N}_{2} \mathrm{O}, \mathrm{NO}_{\mathrm{x}}$, VOCs, $\mathrm{CO}, \mathrm{SO}_{2}$, carbonaceous aerosols, $\mathrm{HFCs}$, $\mathrm{PFCs}$, and $\mathrm{SF}_{6}$. Each is associated with multiple human activities that are explicitly modeled in GCAM.
} 
An important feature of the GCAM is that energy, agriculture, forestry, and land markets are integrated with the extent of unmanaged ecosystems and the terrestrial carbon cycle. The GCAM thus produces outputs that include not only emissions of 15 greenhouse gases and aerosols but also agricultural prices, land use, and stocks of terrestrial carbon.

The GCAM energy system includes primary energy resources, production, energy transformation to final fuels, and the employment of final energy forms to deliver energy services such as passenger kilometers in transport or space conditioning for buildings. Energy supplied from depletable resources, namely fossil fuels and uranium, depends on the abundance and grade of available resources as well as available extraction technologies. As fossil fuel and uranium resources are depletable they exhibit increasing costs in the absence of significant technical change. As more attractive resources are consumed, less attractive resources are exploited and ceteris paribus, costs rise. Renewable resources like wind and solar are produced from graded renewable resource bases. As discussed below, bioenergy availability depends on the availability and character of land resources, technology options for production, and competing land use options.

Primary energy forms include liquids, gases, coal, bioenergy, uranium, hydropower, and solar energy. Primary energy forms are refined and transformed into end-use energy forms. End-use energy forms are refined liquids, refined gas, coal, commercial solid bioenergy, hydrogen, and electricity. Final energy forms are used in the buildings, industry, and transport sectors. Technologies for producing, transforming and utilizing energy are assumed to evolve over time.

GCAM is a technology-rich model. It contains detailed representations of technology options in all of the economic components of the system. Technology choice is determined by 
market competition. Individual technologies compete for market share based on their technology characteristics (efficiency in the production of products from inputs), cost of inputs and price of outputs. The market share captured by a technology increases as its costs decline, but GCAM uses a probabilistic model of market competition and not a "winner take all" model of cost competition.

The GCAM agriculture, land use, land cover, terrestrial carbon cycle module determines the demands for and production of products originating on the land, the prices of these products, the allocation of land to competing ends, the rental rate on land, and the carbon stocks and flows associated with land use. Land is allocated between alternative uses based on expected profitability, which in turn depends on the productivity of the land-based product (e.g. mass of harvestable product per ha), product price, the rental rate on land, and non-land costs of production (labor, capital, fertilizer, etc.). The productivity of land-based products is subject to change over time based on future estimates of crop productivity change. A more complete description of the agriculture and land use component of GCAM can be found in Wise et al. (2009a).

There are three types of bioenergy in the GCAM: traditional bioenergy, bioenergy from waste products, and purpose-grown bioenergy. Traditional bioenergy consists of straw, dung, fuel wood and other energy forms that are utilized in an unrefined state in the traditional sector of an economy. Traditional bioenergy use, although significant in developing nations, is a relatively small component of global energy. We model traditional biomass as becoming less economically competitive as regional incomes increase over the century.

Bioenergy from waste products includes fuels that are consumed in the modern sectors of the economy, but which are byproducts of another activity, for example black liquor in the pulp 
and paper industry or crop residues in agriculture. The availability of byproduct energy feedstocks is determined by the underlying production of primary products and the cost of collection. The total potential waste available is calculated as the total mass of the crop less the portion that is harvested for food, grains, and fibers, and the amount of biomass needed to prevent soil erosion and nutrient loss and sustain the land productivity. The amount of potential waste that is converted to bioenergy is based on the price of bioenergy. However, the bioenergy price does not affect production of the crop from which the waste is derived. For example, an increase in the price of bioenergy would increase the share of the wheat straw collected for use as bioenergy, but the higher bioenergy price would not affect the total production of wheat. Instead, the higher bioenergy price would result in more production of purpose-grown energy crops, discussed next.

The third category of bioenergy is purpose-grown energy crops. Purpose-grown bioenergy refers to crops whose primary purpose is the provision of energy. These include, for example, switchgrass and woody poplar. We consider only "second generation" cellulosic bioenergy crops. Non-cellulosic crops, e.g. oils and sugars, are not included as potential purpose-grown bioenergy feedstocks in this analysis.

The profitability of purpose-grown, "second-generation" bioenergy depends on the expected profitability of raising and selling that crop relative to other land-use options in GCAM. This in turn depends on numerous other model factors including bioenergy crop productivity (which in turn depends on the character of available land as well as crop type and technology), the rental rate on land, non-energy costs of crop production, cost and efficiency of transformation of purpose-grown bioenergy crops to final energy forms (including liquids, gases, solids, electricity, and hydrogen), cost of transportation to the refinery, and the price of final energy forms. The 
price of final energy forms is determined endogenously as a consequence of competition between alternative energy resources, transformation technologies, and technologies to deliver end-use energy services. In other words, prices are determined so as to match demand and supplies in all energy markets.

A variety of crops could potentially be grown as bioenergy feedstocks. The productivity of those crops will depend on where they are grown — which soils they are grown in, climate characteristics and their variability, whether or not they are fertilized or irrigated, the availability of nitrogen and other minerals, ambient $\mathrm{CO}_{2}$ concentrations, and their latitude. In this analysis we assume that a generic bioenergy crop, based on switchgrass, can be grown in any region. Productivity is based on region-specific climate and soil characteristics and varies by a factor of three across the GCAM regions.

In this paper we consider the possibility that bioenergy could be used in the production of electric power and in combination with technologies to capture and store $\mathrm{CO}_{2}$ emissions in geological reservoirs (CCS). This particular technology combination is of interest because bioenergy obtains its carbon from the atmosphere and if that carbon were to be captured and isolated permanently from the atmosphere the net effect of the two technologies would be to produce energy with negative $\mathrm{CO}_{2}$ emissions.

We assume that CCS technology is available for application to large, point-source emissions facilities. These include electric power generation, hydrogen production, cement manufacture, and large industrial facilities. Complete documentation of our modeling of CCS technologies, as well as our modeling of all of the technologies in the energy system, is provided in Clarke et al., 2007b. 


\section{The Reference Scenario}

The reference scenario in this paper is based on the scenario developed for the U.S. Climate Change Science Program (Clarke, et al., 2007a,b). The scenario includes a global population that peaks in 2065 at more than 9 billion people before declining. Global GDP grows by an order of magnitude over the coming century driven by significant growth in the developing regions. A full description of GCAM and the current demographic, economic, resource, and technology assumptions are provided in Clarke et al. (2008), accessible at http://www.pnl.gov/science/pdf/PNNL18075.pdf.

The reference scenario includes continued growth in global energy consumption (Figure 1, Panel A) and electric power generation (Figure 1, Panel B). The production and use of renewable energy grows significantly over the coming century. However, global energy consumption continues to be dominated by fossil fuels use.

Future global land allocation (Figure 1, Panel C) in the GCAM model is calculated assuming that farmers maximize profit. In the reference scenario, this leads to declines in forest land to accommodate increases in crop land and land for bioenergy. From 2005 to 2050, growth in population and meat consumption result in increases in global crop land. However, after 2050, crop land stabilizes due to increasing crop productivity and declining population. The net effect of changes in land use throughout the century is that land-use change emissions decline from a little more than $4 \mathrm{GtCO}_{2}$ /year in 2005 to approximately $1 \mathrm{GtCO}_{2}$ /year by the end of the century (Figure 1, Panel D). Global anthropogenic $\mathrm{CO}_{2}$ emissions continue to be dominated by fossil fuel and industrial emissions (Figure 1, Panel D), due to the continued dependence on fossil fuels in the energy system. 


\section{Policy Scenarios}

The policy scenarios in this paper are based on those developed for the EMF 22 international subgroup (Clarke et al., 2009). The EMF22 international transition subgroup explores the implications of imperfect cooperation and the feasibility of several climate targets. The subgroup explored 10 scenarios in which anthropogenic climate change was limited to three different levels $4.5 \mathrm{~W} / \mathrm{m}^{2}, 3.7 \mathrm{~W} / \mathrm{m}^{2}$ and $2.6 \mathrm{~W} / \mathrm{m}^{2}$, with and without overshoot. In the GCAM team's first contribution to the EMF22 exercise, we focused on the challenges associated with limiting climate change to $2.6 \mathrm{~W} / \mathrm{m}^{2}$ (Calvin et al., 2009a). In this paper, we examine the issue of land-use leakage and instead narrow our attention to two (Table 1) of the EMF22 scenarios. These scenarios limit radiative forcing from Kyoto gases ${ }^{2}$ to $3.7 \mathrm{~W} / \mathrm{m}^{2}$, which corresponds to a 550 ppm $\mathrm{CO}_{2}$-equivalent concentration, with immediate accession by all regions of the world (IA_3.7) and with delayed accession (DA_3.7). Both are overshoot scenarios where radiative forcing is allowed to rise above the 2100 target earlier in the century, but must decline to 3.7 $\mathrm{W} / \mathrm{m}^{2}$ by 2100 .

\begin{tabular}{|c|c|c|c|}
\hline \multicolumn{4}{|c|}{ Table 1: Climate Change Limitation Scenarios * } \\
\hline $\begin{array}{c}\text { Radiative } \\
\text { Forcing Limit }\end{array}$ & $\begin{array}{c}\mathrm{CO}_{2} \text { Equivalent } \\
\text { Concentration }\end{array}$ & Immediate Accession & Delayed Accession \\
\hline $3.7 \mathrm{~W} / \mathrm{m}^{2}$ & $550 \mathrm{ppm} \mathrm{CO}$-e & IA_3.7 & DA_3.7 \\
\hline $\begin{array}{c}\text { * Note that all scenarios are defined to achieve the climate limitation goal in the year 2100 without regard to prior } \\
\text { values for radiative forcing. }\end{array}$
\end{tabular}

Emissions mitigation in GCAM is in general achieved by the imposition of an economywide carbon tax. This tax is applied to all carbon emissions, including not only fossil fuel and industrial emissions, but also land-use change emissions. The "immediate accession" (IA)

\footnotetext{
${ }^{2}$ The gases included are $\mathrm{CO}_{2}, \mathrm{CH}_{4}, \mathrm{~N}_{2} \mathrm{O}, \mathrm{SF}_{6}, \mathrm{C}_{2} \mathrm{~F}_{4}$, and HFCs. The radiative forcings calculated do not include the cooling effects of aerosols or the warming effects from the Montreal gases.
} 
scenarios are characterized by perfect when and where flexibility. Thus, the carbon tax is assumed to be implemented to achieve the climate goal in a cost-effective manner, which requires the carbon tax to rise at the rate of interest plus the rate of ocean carbon uptake (Hotelling, 1938; Peck and Wan, 1996; Edmonds et al., 2008). The initial carbon tax of this Hotelling-Peck-Wan price path is adjusted to ensure that the radiative forcing target is met in the specified year. Carbon taxes in subsequent years are prescribed by the exponential rate of increase. Prescribing a carbon tax that rises at the interest rate ensures that the marginal cost of abatement is constant across time when viewed from any point in time, and thus, exhausts all opportunities for arbitrage across time. When carbon is stored a credit of identical magnitude to the carbon tax is paid. Note that in scenarios in which total anthropogenic carbon emissions become negative that the carbon tax is no longer a source of revenue to governments but rather a net fiscal obligation.

In the delayed accession (DA) scenarios, we achieve the policy goal through a HotellingPeck-Wan carbon tax path uniformly applied to all covered emissions. However, these scenarios do not assume immediate international cooperation and instead assume three different accession dates for Groups 1, 2 and 3 (Table 2). Group 1 (roughly Annex I less the Russian Federation) begins emissions mitigation immediately and imposes carbon taxes that follow the same patterns as in the immediate accession scenarios. Group 2 begins emissions mitigation in $2036,{ }^{4}$ while Group 3 starts to reduce emissions in 2051. Because the tax is rising exponentially, regions would suffer a carbon-price shock if they imposed the Group 1 price immediately (see Edmonds

\footnotetext{
${ }^{3}$ Annex I refers to a list of developed nations plus the economies in transition from the Framework Convention on Climate Change (United Nations, 1992). Thus, Annex I included OECD nations, Eastern Europe, and the Russian Federation.

${ }^{4}$ The EMF22 Specification calls for Group 2 to start emissions mitigation in 2031. However, GCAM's 15 year time step requires mitigation to either begin in 2021 or 2036. To err on the side of caution, we have delayed their accession 5 years until 2036. Altering this assumption will have an impact on the achievability of low stabilization targets; the $3.7 \mathrm{~W} / \mathrm{m}^{2}$ not-to-exceed scenario is technically possible in GCAM if Group 2 enters the regime in 2021, but not if they delay until 2036.
} 
et al., 2008). Instead, we assume that when Groups 2 and 3 enter the climate regime, their initial tax is less than the current prevailing Group 1 tax. Specifically, we assume that Groups 2 and 3 impose the 2012 Group 1 tax in their year of accession. Carbon taxes then rise linearly over twenty years to meet the prevailing Group 1 price. Delayed accession assumptions are summarized in Table 2.

\begin{tabular}{|c|l|c|}
\hline \multicolumn{2}{|c|}{ Table 2: Delayed Accession (DA) } \\
\hline Region & \multicolumn{1}{|c|}{ GCAM regions } & Period of Policy Phase In \\
\hline Group 1 & $\begin{array}{l}\text { USA, Canada, W. Europe, E. Europe, Japan, } \\
\text { Australia \& NZ }\end{array}$ & 2012 to 2020 \\
\hline Group 2 & $\begin{array}{l}\text { The Former Soviet Union, India, China, Latin } \\
\text { America }\end{array}$ & 2036 to 2050 \\
\hline Group 3 & Korea, South \& East Asia, Middle East, Africa & 2051 to 2065 \\
\hline
\end{tabular}

\section{Defining the Leakage Scenarios}

We measure "leakage" as the difference between emissions reductions in participating regions and global emissions reductions. Leakage is the sum of two components: industrial leakage and land-use leakage. ${ }^{5}$ By definition, leakage only occurs in scenarios in which participation in international emissions limitation coalitions is incomplete. In this paper, we focus only on the land-use component of leakage and consider two pathways by which land-use leakage might arise.

In section 6, we will explore the leakage that could occur as a consequence of policies designed to expand carbon storage on land in regions mitigating emissions. When mitigating regions place an explicit value on terrestrial carbon emissions, those regions have incentives to trade low carbon density land (e.g., crop land) for high carbon density land (e.g., forest systems).

\footnotetext{
${ }^{5}$ For the purposes of this paper, the term "land-use leakage" refers to two related processes: the shift of land cover from participating regions to non-participating regions and the increase in land-use change emissions resulting from that shift in land cover.
} 
Decreasing crop land in mitigating regions could result in increases in crop land in nonmitigating regions, which in turn could lead to deforestation in those regions. Thus, the expansion of forests in mitigating regions could result in the clearing of forests in non-mitigating regions. Because the destruction of mature forests releases many years of accumulated carbon storage, the net effect of afforestation policies could, for some period of time, lead to an increase in global land-use emissions from net deforestation.

We explore this first driver of land-use leakage by examining a set of alternative terrestrial policy implementations assuming no bioenergy production or use. By eliminating bioenergy production and use, these scenarios highlight the role of terrestrial policies designed to expand terrestrial carbon reservoirs. Table 3 identifies three policy variants of the delayed participation scenarios given in Table 1 that we have defined to help identify more clearly the magnitude and nature of land-use carbon leakage.

In Section 7, we discuss the second potential pathway for land-use leakage, which involves purpose-grown bioenergy crops. If bioenergy is treated as a carbon-neutral fuel and is therefore exempted from greenhouse gas emissions penalties, then climate policies that penalize fossil fuel carbon emissions would increase the demand for bioenergy and therefore the demand for land on which to grow it. Increases in the demand for land create pressures to expand the extent of managed lands, potentially resulting in increased deforestation rates. This is the well known indirect land-use change (ILUC) effect that has been identified by Edmonds et al. (2003), Searchinger et al. (2008), Fargione et al. (2008), Schmer et al. (2008) and Wise et al. (2008, 2009). By the definitions used in this paper, increases in land-use change emissions which occur outside the control region are land-use leakage. The magnitude of land-use leakage will depend on the treatment of land in emissions mitigation policies. 
The role of bioenergy in driving land-use leakage is complex, because it derives from an interaction between land-use policies and bioenergy policies. To begin to understand the potential roles of bioenergy in both climate stabilization scenarios and land-use leakage, we define an additional set of scenarios in Section 7 that include the availability of bioenergy as an emissions mitigation option. In this protocol bioenergy is assumed to be available and treated as a renewable energy form with no associated emissions. As noted earlier, indirect land-use change emissions are accounted for, but tracked separately. Bioenergy is allowed to be freely traded in the international market.

We examine these protocols against the background of the two accession regimes defined in Tables 1 and 2, and the land-use policies defined in Table 3. The FFICT land-use policy places no value on terrestrial carbon in any region, while the UCT scenario values terrestrial carbon in mitigating regions only. The UCT+INTM values land-use carbon everywhere and is equivalent to a perfect land-use "offsets" program. The program differs from the "offsets" programs typically discussed in the policy realm in that it values all terrestrial carbon emissions within mitigating and non-mitigating regions. Thus, the program goes beyond simply planting trees within a non-mitigating region, but also ensures that these trees are truly additional, i.e., total stock of terrestrial carbon in that region is increased. It is important to note that the climate constraint in this paper is a long-term target: limiting radiative forcing from Kyoto gases in 2100 to $3.7 \mathrm{~W} / \mathrm{m}^{2}$. Thus, unlike the offsets' programs typically discussed in the policy arena, which focus on annual emissions mitigation, international net terrestrial mitigation (INTM) in this paper reduces the cumulative burden of emissions mitigation on participating regions.

Table 3: Land-use Policies

\begin{tabular}{l|r} 
Land-use Policy & Implementation
\end{tabular}




\begin{tabular}{|c|l|}
\hline FFICT & $\begin{array}{l}\text { Fossil fuel and industrial emissions tax in emissions control regions. Only } \\
\text { fossil fuel and industrial carbon emissions are taxed. Land-use change } \\
\text { emissions are not penalized. }\end{array}$ \\
\hline UCT & $\begin{array}{l}\text { A universal carbon tax in emissions control regions. All carbon emissions } \\
\text { are taxed at the same rate regardless of origin in the emissions control } \\
\text { regions. Thus, the carbon tax on land-use change emissions is identical to } \\
\text { the tax on fossil fuel and industrial emissions. Land-use change emissions in } \\
\text { non-control regions are not penalized. }\end{array}$ \\
\hline UCT+INTM & $\begin{array}{l}\text { A universal carbon tax in emissions control regions. All carbon emissions } \\
\text { are taxed at the same rate regardless of origin in the emissions control } \\
\text { regions. Thus, the carbon tax on land-use change emissions is identical to } \\
\text { the tax on fossil fuel and industrial emissions. In addition, any land-use } \\
\text { change emissions mitigation relative to the reference scenario in non-control } \\
\text { regions is valued at the same rate as in mitigating regions. }\end{array}$ \\
\hline
\end{tabular}

\section{Land-Use Leakage and Terrestrial Carbon Policies}

To isolate the role of land-use policies in emissions mitigation and leakage, we begin with the set of policies outlined in Table 3 assuming no bioenergy is produced or consumed. Figure 2, Panel A shows carbon prices for Group 1 countries. These countries have a positive price of carbon from the outset of the analysis. We report five cases, two immediate accession scenario that are reported for comparison purposes, and the three alternative assumptions about land-use policies, Table 3, under delayed accession. We begin by noting that the lowest cost of reaching $3.7 \mathrm{~W} / \mathrm{m}^{2}$ occurs in the immediate accession scenario with a universal carbon price (IA_UCT). In this scenario, fossil fuel and industrial emissions mitigation is supplemented by terrestrial sequestration. The Group 1 carbon price in the IA_FFICT scenario is one third higher than in the IA_UCT scenario, representing the economic penalty for ignoring land-use emissions mitigation opportunities. The delayed accession scenario that completely ignores land-use (DA_FFICT) has the highest carbon price in Group 1. A lower carbon price is observed when terrestrial carbon is valued in Group 1, that is, in the DA_UCT scenario, even though this scenario does not allow mitigation to be obtained from non-participating regions. As might be 
imagined, the scenario which allows international net terrestrial mitigation (UCT+INTM) has lower carbon prices for Group 1 than the other two delayed accession scenarios. ${ }^{6}$

Delayed accessions scenarios shift global emissions mitigation out further in time, Figure 3. Delayed accessions scenarios have higher global emissions in the near term, and require deeper emissions cuts in the long term. The distribution of emissions across regions varies across the three alternative climate policy environments. Group 1 emissions are universally reduced to a lower value under delayed accession scenarios than under immediate accession scenarios, Figure 3, Panel A. Group 2 and 3 have higher near-term emissions in the delayed accession scenarios but lower emissions in the long-term, Figure 3, Panels B and C.

We note that Group 1 has higher domestic emissions and lower carbon prices in the UCT+INTM scenario than in the DA_UCT scenario. That is, international net terrestrial mitigation leads to lower carbon prices in Group 1 countries.

The size of the program that is implied by our DA_UCT+INTM scenario is not immediately obvious. If we interpret the magnitude of the program as the reduction in total anthropogenic emissions in Groups 2 and 3 during the period before their accession to an emissions mitigation regime, between the DA_UCT scenario and the DA_UCT+INTM scenario, and assign those emissions mitigations to Group 1 (and Group 2 in 2050), then emissions limitation obligations for the DA_UCT+INTM scenario is displayed in Figure 4.

Figure 4 shows that if all of incremental emissions mitigation is assigned to participating regions (that is, no mitigation from non-participating regions are allowed), then emissions

\footnotetext{
${ }^{6}$ It should be noted that all three delayed accession scenarios have higher carbon prices than the two immediate accession scenarios.
} 
reduction obligations ${ }^{7}$ in participating regions are significantly more stringent (compare the dashed red line to the solid orange line). This significantly more stringent limitation contrasts with the lower domestic emissions mitigation in the case where international net terrestrial mitigation is allowed (DA_UCT+INTM). In other words, shifting from an emissions mitigation scheme that does not allow international mitigation to one that does increases total emissions mitigation obligations in Group 1 (and Group 2 between 2035 and 2050), while reducing the domestic mitigation component. The increase in total emissions mitigation obligations is due to the long-term climate target. An offset program with an annual emissions target, like in some recent U.S. bills, would not change the emissions obligations. Such a program would merely shift the abatement across space (i.e., from participating regions to non-participating regions). With a cumulative emissions target, the effect of international net terrestrial mitigation is to shift mitigation across space and time (i.e., mitigation in a scenario with international mitigation occurs earlier in the century than in a scenario without international mitigation). Figure 5 shows emissions mitigation obligations in participating regions, but divides these obligations into domestic reductions (shaded in red) and international mitigation (shaded in green) for the two scenarios. While domestic reductions still dominate the overall mitigation strategy, international mitigation does account for a significant amount of mitigation when allowed.

The INTM case is clearly a lower cost strategy for the world. Both the carbon tax and the total cost of emissions mitigation are smaller in the INTM case than in the case with no international net terrestrial mitigation (DA_UCT). However, whether or not total cost is higher or lower in Group 1 will depend at least in part on whether the international mitigation is purchased in a market in which all permits transactions are at the then prevailing carbon price, or

\footnotetext{
${ }^{7}$ We distinguish between "obligations" and "mitigation". Obligations are the emissions reduction targets assigned to participating regions; these obligations can be met either through domestic emissions reductions or international offsets. "Mitigation," in the context of this paper, refers to domestic emissions reductions.
} 
whether international mitigation is sold as individual projects in which each is sold at it own marginal cost. This amounts to a question of who captures the economic rents associated with land-use change emissions mitigation, the sellers (non-participating regions) or the buyers (participating regions). Estimates of the two extreme scenarios, namely the scenario in which all economic rents are captured by the sellers and buyers respectively are presented in Table 4 and contrasted to the scenario in which terrestrial carbon mitigation is only available domestically, DA_UCT.

Table 4. Total Economic Cost of Emissions Mitigation, Including INTM in Mitigating Regions (Billions of 2005 USD)

DA UCT

DA UCT+INTM (Economic Rent to Sellers)

DA UCT+INTM (Economic Rent to Buyers)

\begin{tabular}{rrrr}
2005 & 2020 & 2035 & 2050 \\
\hline$\$ 0$ & $\$ 23$ & $\$ 169$ & $\$ 1,124$ \\
$\$ 0$ & $\$ 46$ & $\$ 146$ & $\$ 1,004$ \\
$\$ 0$ & $\$ 31$ & $\$ 81$ & $\$ 857$
\end{tabular}

We now turn our attention to the matter of land-use leakage. We first observe that by definition, land-use leakage does not occur in scenarios with immediate accession by all countries. Additionally, since the delayed accession scenarios assume that all regions join in the common emissions mitigation enterprise after the year 2050, it is a phenomenon limited to the first half of the century in these scenarios. Further, land-use leakage does not occur in the DA_FFICT scenario, because all regions have a common, "no land-use policy" policy and in this section, we have assumed no bioenergy. Hence, there is no mechanism by which mitigation actions in one region could affect land use in any other region. Thus, without bioenergy, we are left with two interesting scenarios: DA_UCT and DA_UCT+INTM.

Leakage is a significant issue in the DA_UCT scenario, Figure 6. In 2035 global emissions mitigation is 20 percent lower than emissions mitigations in participating regions. 
That is, one fifth of total anthropogenic emissions mitigation in the coalition regions is negated by increased land-use change emissions in other parts of the world. By comparison, industrial emissions leakage in similar scenarios was significantly lower. For example, Calvin, et al. (2009b) found that maximum industrial leakage was only 6 percent under the same scenario considered in this current study. The effect on the allocation of land in the DA_UCT scenario is shown in Figure 7. Group 1 initiates the mitigation coalition and taxes all carbon emissions, which results in avoided deforestation and afforestation practices as a means of terrestrial carbon sequestration. Since land area is limited, expanding forest land leads to reduced area for crops; however, global demands for food grains remain the same. Therefore, in non-coalition regions we see exactly the opposite, namely increased allocation of land to crops and decreases in forested areas. This transition ends when each region joins the mitigation coalition. For Groups 2 and 3 the date of accession corresponds to the peak in areas allocated to crops. While there is a global shift in land toward forests, Figure 7, Panel D, the economic inefficiencies of the delayed accession regime (such as increased costs of agricultural production) leads to a dietary shift away from ruminant animals. The decreased demand for ruminants reduces pasture land relative to both the reference scenario, Figure 8 , and the immediate accession scenario with a carbon tax on all emissions, IA_UCT, Figure 9.

Note that in Figure 6, the INTM scenario has "negative leakage". In the context of this paper, negative leakage means that global mitigation exceeds mitigation in the participating regions. However, mitigation in non-participating regions is the result of international mitigation paid for by participating regions. Thus, this mitigation is not free and is the result of an explicit terrestrial policy imposed on these regions. 
In addition to the economic consequences of leakage, we also examine the environmental consequences by assessing the loss in terrestrial carbon stock for each group and scenario (Table 5). From this table, we see that the reference case results in a carbon loss of $120 \mathrm{GtCO}_{2}$. As previously noted, without bioenergy or a land-use policy (e.g., the FFICT scenarios), the energy system carbon price does not get communicated to the terrestrial system. Thus, the two FFICT scenarios have the same loss in carbon stock $\left(120 \mathrm{GtCO}_{2}\right)$ as the reference scenario. The reduced deforestation and afforestation practices that participating regions engage in under the UCT regime result in significant reductions in the carbon stock lost. For example, the IA_UCT scenario has a loss in carbon stock of only $80 \mathrm{GtCO}_{2}, 2 / 3$ of the loss in the reference scenario. Similarly, Group 1 exhibits reduced losses in carbon stock in the DA_UCT and DA_UCT+INTM cases. Table 5 also shows increases in carbon stock lost in Groups 2 and 3 under the DA_UCT scenario; these are the physical effects of land-use leakage. The increases can be substantial; Group 3 nearly doubles its loss in terrestrial carbon stock. The inclusion of international mitigation reduces the loss in carbon stock below both the DA_UCT and the reference scenario values for all groups.

\begin{tabular}{|l|l|l|l|l|}
\hline $\begin{array}{l}\text { Table 5. Total Loss in Terrestrial Carbon Stock from } 2005 \text { to } 2050\left(\mathrm{GtCO}_{2}\right) \\
\text { in scenarios without bioenergy }\end{array}$ \\
\hline Scenario & Group 1 & Group 2 & Group 3 & Global \\
\hline Reference & 33.3 & 47.3 & 39.6 & 120.2 \\
\hline IA_FFICT & 33.3 & 47.3 & 39.6 & 120.2 \\
\hline IA_UCT & 24.8 & 35.0 & 20.1 & 79.9 \\
\hline DA_FFICT & 33.3 & 47.3 & 39.6 & 120.2 \\
\hline DA_UCT & 22.0 & 64.6 & 99.3 & 185.9 \\
\hline DA_UCT+INTM & 23.7 & 45.5 & 25.2 & 94.4 \\
\hline
\end{tabular}




\section{Land-Use Leakage and Bioenergy}

The previous section discussed land-use leakage from emissions mitigation policies that address land-use without the complication of bioenergy production and use. In this section, we prescribe land-use policy in the context of emissions mitigation and ask whether or not the addition of bioenergy as a technology option leads to land-use leakage. Recall that this is a different question than whether or not bioenergy production leads to ILUC, though the two phenomena are related. As we showed in the previous section, land-use leakage depends on the treatment of land use in the context of emissions mitigation. We therefore consider three alternative land-use policy environments and ask the question, does the addition of bioenergy induce leakage relative to a case with the land-use policy alone, i.e. without bioenergy.

Leakage results for the various land-use policies are shown in Figure 10, which compares the effects of land-use policies alone (from Figure 6, shown in solid lines) and land-use leakage effects from bioenergy shown in dashed lines. The greatest land-use leakage associated with bioenergy production is observed in the scenario that fails to value carbon, the DA_FFICT scenario. Note that absent bioenergy no leakage effects were observed because there was no mechanism by which emissions mitigation policies in one part of the world could be communicated to other parts of the world. The introduction of bioenergy production creates a mechanism for affecting global land-use as a consequence of emissions mitigation actions. Furthermore, the effect is very large, with 80 percent leakage in the peak year, 2050. The mechanism creating the land-use leakage is ILUC. The increase in demand for bioenergy in mitigating regions leads to expansion of bioenergy feedstock production into unmanaged ecosystems and forest land internationally, which in turn causes a pulse of carbon emissions 
from land use conversion which is almost as large as total mitigation by Groups 1 and 2 in the year $2050 .^{8}$

Valuing carbon in mitigating regions dramatically reduces the effect as observed in the DA_UCT scenarios. However, even in the DA_UCT scenario land-use leakage is observed for from both the land-use policy alone and from the addition of bioenergy as a mitigation option. (The total effect of bioenergy and land-use policy would be the sum of the two effects.) In contrast, the UCT+INTM policy, allowing land-use mitigation to be obtained from anywhere in the world, eliminates leakage and creates situation where global mitigation is actually larger than mitigation in participating regions (negative leakage by the definition provided in the previous section). Furthermore, the introduction of bioenergy widens the gap between global mitigation and mitigation in participating regions.

Again, we assess the impact of land-use leakage on the physical world by assessing the total loss in terrestrial carbon stock across regions and scenarios when bioenergy is included (Table 6). The addition of bioenergy results in slight increases in the amount of carbon stock lost in the reference scenario as land is cleared to grow bioenergy. In the IA_UCT, the DA_UCT, and the DA_UCT+INTM scenarios, the inclusion of bioenergy leads to a slight reduction in the amount of carbon stock lost. The largest difference between the cases with and without bioenergy, however, is in the FFICT scenarios. Recall that without bioenergy the FFICT scenarios had the same carbon loss as the reference scenario. Including biomass, however, results in significant increases in land clearing and carbon stock loss; the IA_FFICT has more

\footnotetext{
${ }^{8}$ The scenarios included here allow for trade in bioenergy feedstocks. With this assumption, deforestation occurs as bioenergy production expands globally to meet the increased demand in the mitigating regions. However, land-use leakage would occur even absent trade in bioenergy. If bioenergy trade were restricted, mitigating regions would reserve land for forests and bioenergy production. Since land is limited, land for food crops would shift to nonmitigating regions resulting in deforestation and land-use change emissions in these regions.
} 
than 2.5 times the loss in carbon stock and the DA_FFICT has more than 3.5 times the loss in carbon stock as the reference scenario.

\begin{tabular}{|l|l|l|l|l|}
\hline $\begin{array}{l}\text { Table 6. Total Loss in Terrestrial Carbon Stock from } 2005 \text { to } 2050\left(\mathrm{GtCO}_{2}\right) \\
\text { in scenarios where bioenergy is included }\end{array}$ \\
\hline Scenario & Group 1 & Group 2 & Group 3 & Global \\
\hline Reference & 34.6 & 49.5 & 40.9 & 124.9 \\
\hline IA_FFICT & 65.2 & 143.3 & 115.8 & 324.2 \\
\hline IA_UCT & 22.5 & 27.8 & 13.6 & 63.9 \\
\hline DA_FFICT & 88.1 & 223.8 & 139.0 & 450.9 \\
\hline DA_UCT & 17.2 & 59.4 & 92.4 & 169.0 \\
\hline DA_UCT+INTM & 18.6 & 41.3 & 21.9 & 81.8 \\
\hline
\end{tabular}

Finally, we note that the inclusion of bioenergy reduces the carbon price in all scenarios.

That is, regardless of the policy environment, it is cheaper to limit radiative forcing to $3.7 \mathrm{~W} / \mathrm{m}^{2}$ with bioenergy than without bioenergy.

\section{Discussion}

This paper has begun a discussion of the potential for land-use carbon emission leakage. We have shown that the potential for carbon leakage from land-use is large, both compared to total domestic emissions mitigation and relative to industrial carbon leakage. We identified two potential mechanisms that could drive land-use leakage: land-use policies and bioenergy production. Each source could be large relative to leakage rates from industrial emissions policies. We also found that leakage was highly dependent on the policy environment. In fact, depending on the policy environment, land-use leakage could either be a large negative or positive feedback to domestic emissions mitigation efforts.

We also considered international net terrestrial mitigation to supplement domestic emissions mitigation in the context of a long-term climate goal. We found that international mitigation reduced global costs of limiting radiative forcing to $3.7 \mathrm{~W} / \mathrm{m}^{2}$; however, that cost reduction could be realized only if mitigating regions took on more ambitious commitments to 
emissions reduction. We further observed that the total social cost to mitigating coalition members of the combined domestic emissions mitigation and international net terrestrial mitigation programs was influenced by the disposition of the economic rents associated with land-use emissions mitigation policies.

While this paper has examined imperfect international policy architectures, it has nonetheless focused on relatively idealized land-use mitigation policy instruments. While we were able to draw insights from the use of idealized policy instruments, we leave the harder job of translation to workable "real world" policy architectures to others. With land-use this task is particularly difficult.

\section{References}

Babiker, M.H. 2005. “Climate Change Policy, Market Structure, and Carbon Leakage.” Journal of International Economics, 65: 421-445.

Bollen, J. T. Manders, and H. Timmer. 2000. "Decomposing Carbon Leakage-An Analysis of the Kyoto Protocol.” Third Annual Conference on Global Economic Analysis, Melbourne, Australia.

Brenkert A, S Smith, S Kim, and H Pitcher. 2003. Model Documentation for the MiniCAM. PNNL-14337, Pacific Northwest National Laboratory, Richland, Washington.

Burniaux, J-M, J. Oliveira Martins. 2000. “Carbon Emission Leakage: A General Equilibrium View." OECD Economics Department Working Paper No. 242, Paris. 
Calvin, Katherine, Jae Edmonds, Ben Bond-Lamberty, Leon Clarke, Sonny Kim, Page Kyle, Steve Smith, Allison Thomson, Marshall Wise (2009a). "2.6: Limiting Climate Change to 450 ppm $\mathrm{CO}_{2}$ Equivalent in the 21st Century,” Energy Economics [In Press] doi:10.1016/j.eneco.2009.06.006.

Calvin, Katherine, Pralit Patel, Allen Fawcett, Leon Clarke, Karen Fisher-Vanden, Jae Edmonds, Sonny Kim, Ron Sands, Marshall Wise (2009b). "The Distribution and Magnitude of Emissions Mitigation Costs in Climate Stabilization under less than Perfect International Cooperation:

SGM Results.” Energy Economics [In Press] doi:10.1016/j.eneco.2009.06.014.

Clarke, L., J. Edmonds, H. Jacoby, H. Pitcher, J. Reilly, and R. Richels. 2007a. CCSP Synthesis and Assessment Product 2.1, Part A: Scenarios of Greenhouse Gas Emissions and Atmospheric Concentrations. U.S. Government Printing Office, Washington DC.

Clarke, L., J. Lurz, M. Wise, J. Edmonds, S. Kim, S. Smith, H. Pitcher. 2007b. Model Documentation for the MiniCAM Climate Change Science Program Stabilization Scenarios: CCSP Product 2.1a. PNNL Technical Report. PNNL-16735.

Clarke, L., M.A. Wise, J.A. Edmonds, M. Placet, P. Kyle, K. Calvin, S. Kim, S. Smith. 2008. $\mathrm{CO}_{2}$ Emissions Mitigation and Technological Advance: An Updated Analysis of Advanced Technology Scenarios (Scenarios Updated January 2009). PNNL-18075 (December, 2008). 82 pages. 
Clarke L, Edmonds J, Krey V, Richels R, Tavoni M, Rose S. EMF22 International Scenarios Overview. Energy Economics 2009; forthcoming

Edmonds, J., L. Clarke, J. Lurz and M. Wise. 2008. "Stabilizing $\mathrm{CO}_{2}$ Concentrations with Incomplete International Cooperation,” Climate Policy, 8:355-376. [PNNL-SA-16932].

Edmonds, J.A. et al., “The Potential Role of Biotechnology in Addressing the Long-term Problem of Climate Change in the Context of Global Energy and Ecosystems," Greenhouse Gas Control Technologies, J. Gale and Y. Kaya (eds.). Pergamon, Amsterdam. pp. 1427-1432 (2003).

Edmonds, J. and J. Reilly. 1985. Global Energy: Assessing the Future, Oxford University Press, New York. 1985.

Felder, S. and T.F. Rutherford. 1993. "Unilateral CO2 Reductions and Carbon Leakage: The Consequences of International Trade in Oil and Basic Materials." Journal of Environmental Economics and Management, 25: 162-176.

Fargione, Joseph, Jason Hill, David Tilman, Stephen Polasky, and Peter Hawthorne. 2008. “Land Clearing and the Biofuel Carbon Debt.” Science 319. February 29, 2008.

IPCC (Intergovernmental Panel on Climate Change). 2007. Climate Change 2007: Mitigation of Climate Change. Contribution of Working Group III to the Fourth Assessment Report of 
the Intergovernmental Panel on Climate Change. B. Metz, O.R. Davidson, P.R. Bosch, R. Dave, L.A. Meyer (eds), Cambridge University Press, Cambridge, United Kingdom and New York, NY, USA., 851 pp.

Kim, Son H., Jae Edmonds, Josh Lurz, Steven J. Smith, and Marshall Wise. 2006. "The Objectoriented Energy Climate Technology Systems (ObjECTS) Framework and Hybrid Modeling of Transportation in the MiniCAM Long-Term, Global Integrated Assessment Model,” The Energy Journal., Special Issue: Hybrid Modeling of Energy-Environment Policies: Reconciling Bottom-up and Top-down, pp.63-91. [PNWD-SA-7256].

Kuik, O. and R. Gerlagh. 2003. “Trade Liberalization and Carbon Leakage.” The Energy Journal, 24(3): 97-119.

Murray, Brian C., McCarl, Bruce A., Lee, Heng-Chi. 2004. "Estimating Leakage from Forest Carbon Sequestration Programs.” Land Economics 80: 109-124.

Paltsev, S.V. 2001. "The Kyoto Protocol: Regional and Sectoral Contributions to the Carbon Leakage." The Energy Journal, 22(4):53-79.

Peck, SC and YH Wan. 1996. “Analytic Solutions of Simple Greenhouse Gas Emission Models." Chapter 6 of Economics of Atmospheric Pollution, eds EC Van Ierland and K Gorka. Springer Verlag, New York. 
Reinaud, J. 2008. “Climate Policy and Carbon Leakage_-Impacts of the European Emissions Trading Scheme on Aluminium.” OECD/International Energy Agency. October.

Richels, R., T. Rutherford, G. Blanford, and L. Clarke. 2008. "Managing the transition to climate stabilization," Climate Policy, 7(5):409-428.

Schmer et al., Proc. Natl. Acad. Sci. USA 105, 464 (2008).

Searchinger, Timothy et al., Science 319, 1238 (2008).

United Nations. 1992. Framework Convention on Climate Change. United Nations, New York.

Watson, R.T., I. Noble, B. Bolin, N.H. Ravindranath, D.J. Verardo, D.J. Dokken. 2000. LandUse, Land-Use Change and Forestry: A Special Report of the IPCC. Cambridge University Press.

Wise, Marshall A., Katherine V. Calvin, Allison M. Thomson, Leon E. Clarke, Benjamin BondLamberty, Ronald D. Sands, Steven J Smith, Anthony C. Janetos, James A. Edmonds. 2009a. "The Implications of Limiting CO2 Concentrations for Agriculture, Land Use, Land-use Change Emissions and Bioenergy" Pacific Northwest National Laboratory. PNNL-18341. http://www.pnl.gov/gtsp/publications/2009/200902_co2_landuse.pdf. 
Wise, MA, KV Calvin, AM Thomson, LE Clarke, B Bond-Lamberty, RD Sands, SJ Smith, AC Janetos, JA Edmonds. 2009b. Implications of Limiting $\mathrm{CO}_{2}$ Concentrations for Land Use and Energy. Science. 324:1183-1186. May 29, 2009. 
Figure 1: The Reference Scenario

\begin{tabular}{|r|r|r|r|}
\hline Panel A Global Primary Energy by Fuel & Panel B Global Electricity Generation by \\
Technology
\end{tabular}


Figure 2: $\quad$ Carbon price path by Group 2005 to 2095 (6 cases)

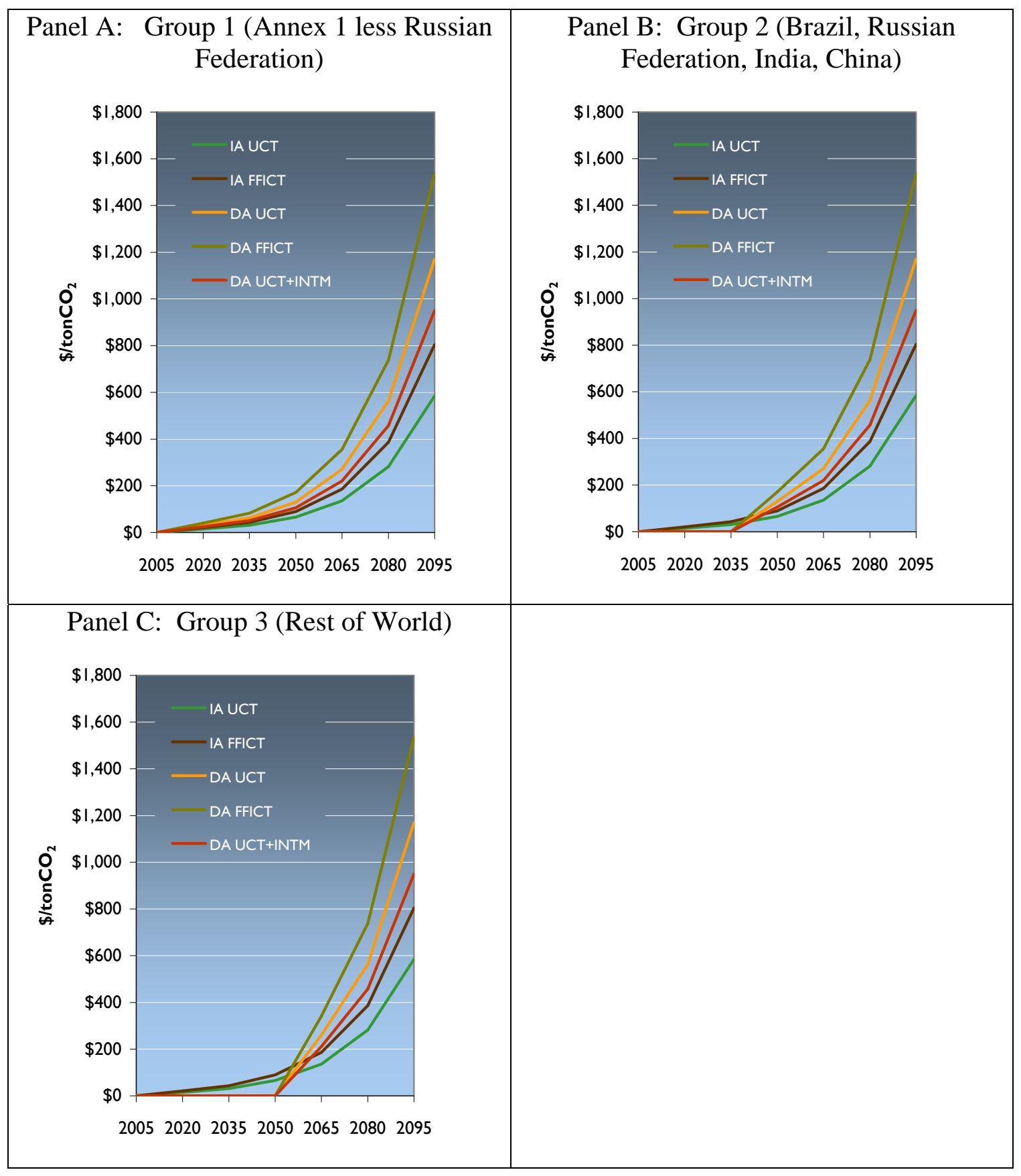


Figure 3: Total Anthropogenic Emissions by Group 2005 to 2095 (5 cases)

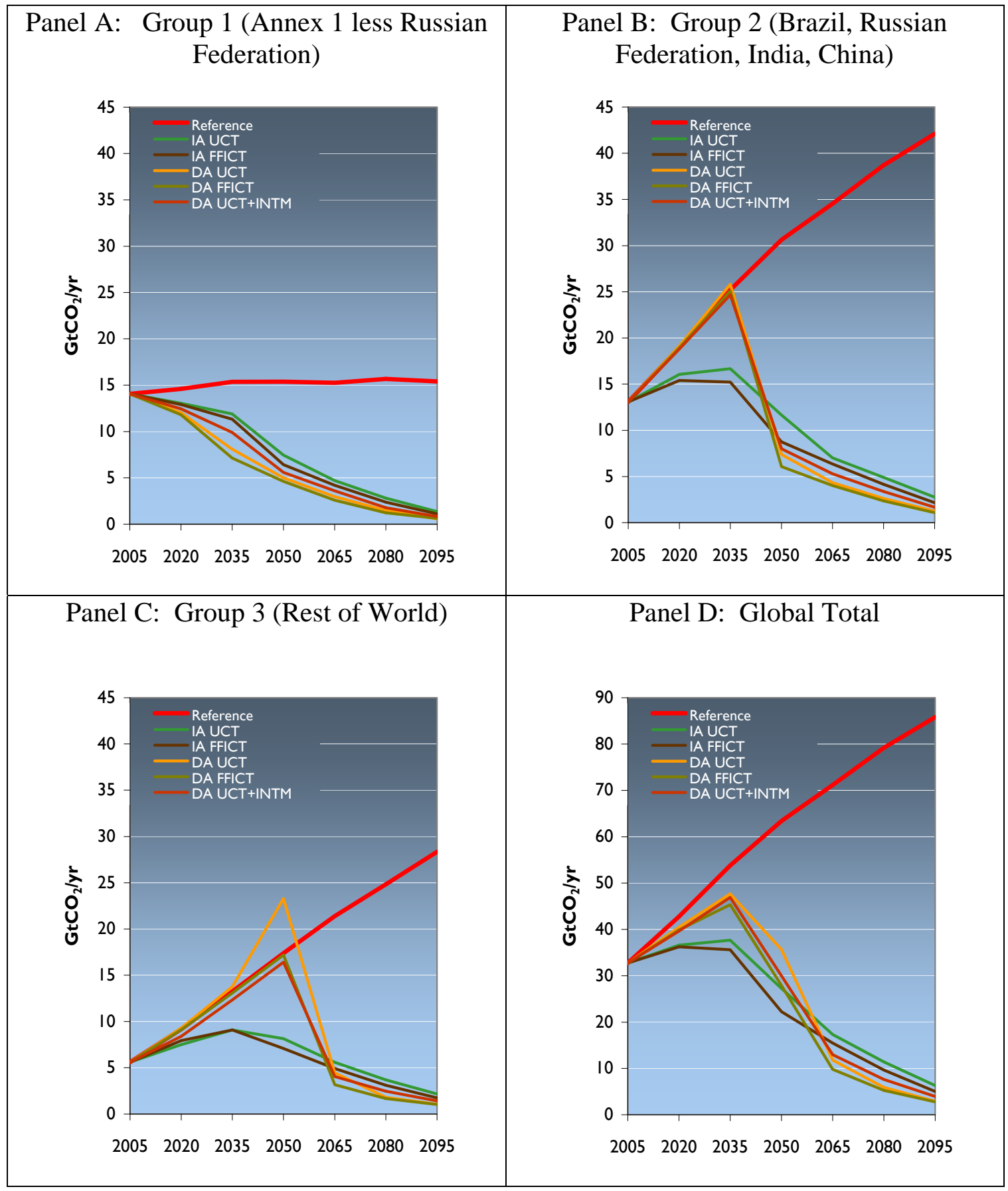


Figure 4: $\quad$ Total Anthropogenic Emissions within Group 1 and Emissions Limitation Obligations by Group 1 in the Offset Case, 2005 to 2095

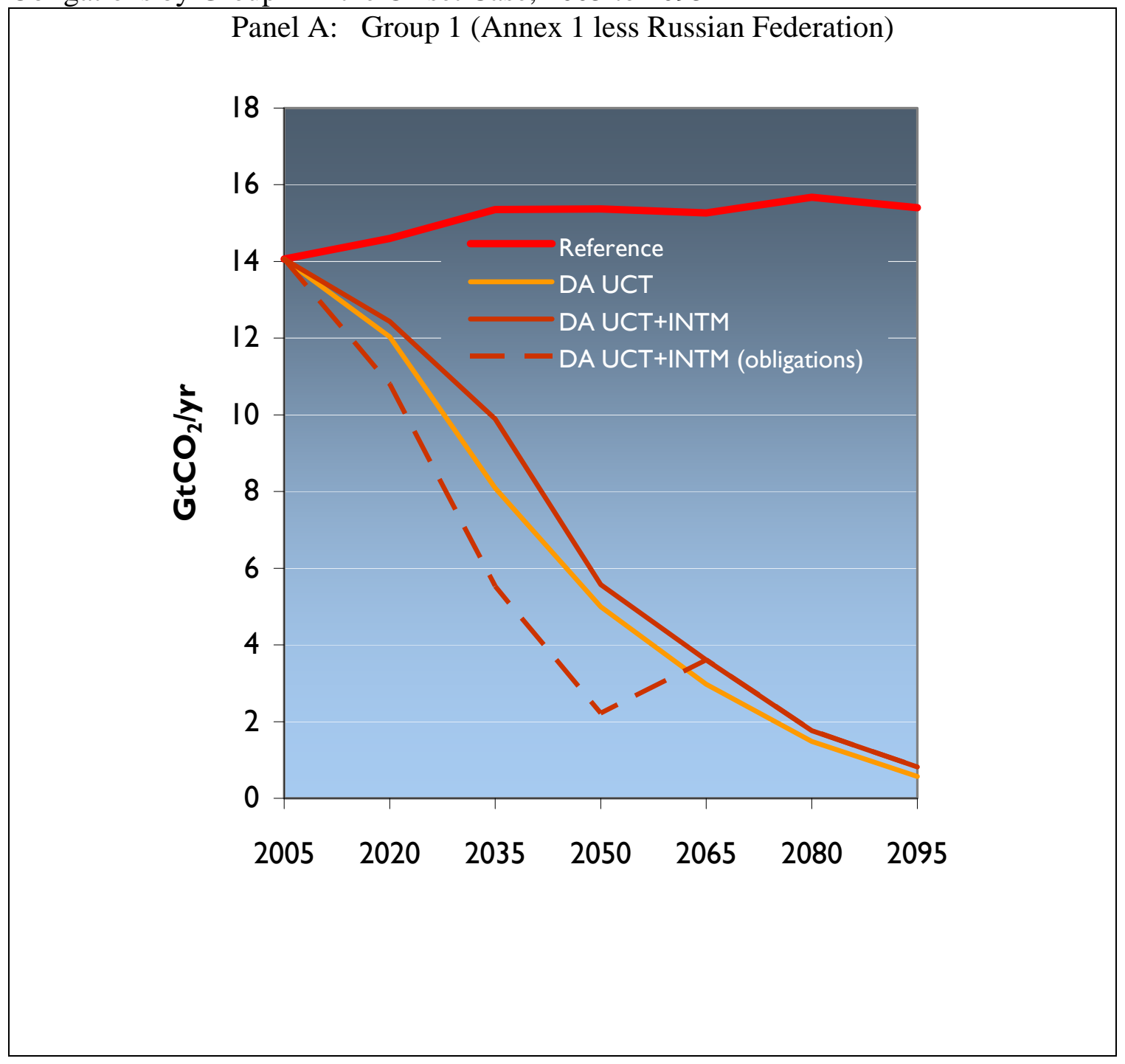


Figure 5: Group 1 Mitigation Obligations and Location of Mitigation

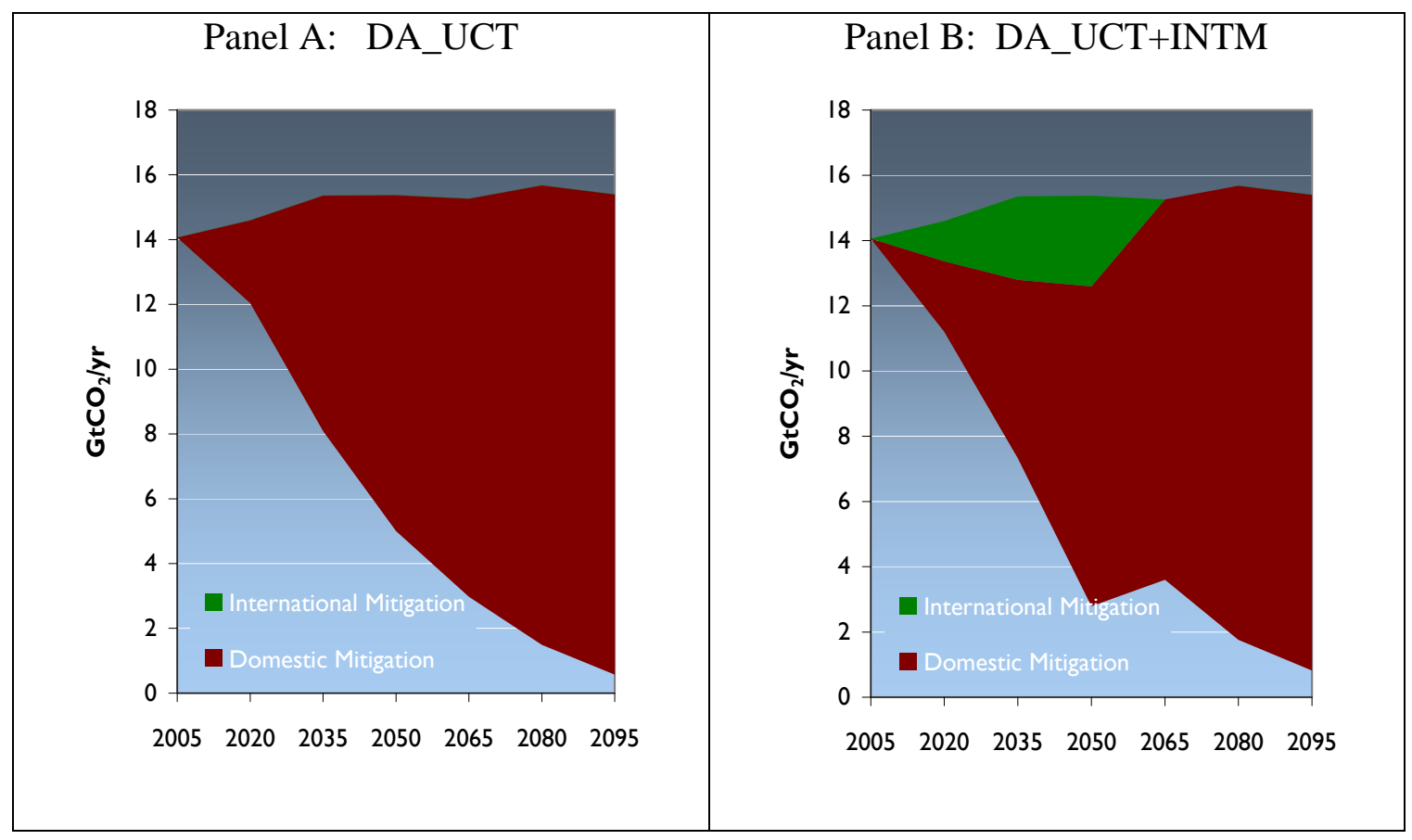


Figure 6: Total Land-use Leakage Associated with Land-use Policies from Coalition Regions, Measured as a Percentage of Total Anthropogenic Emissions Mitigations, 2005 to 2095

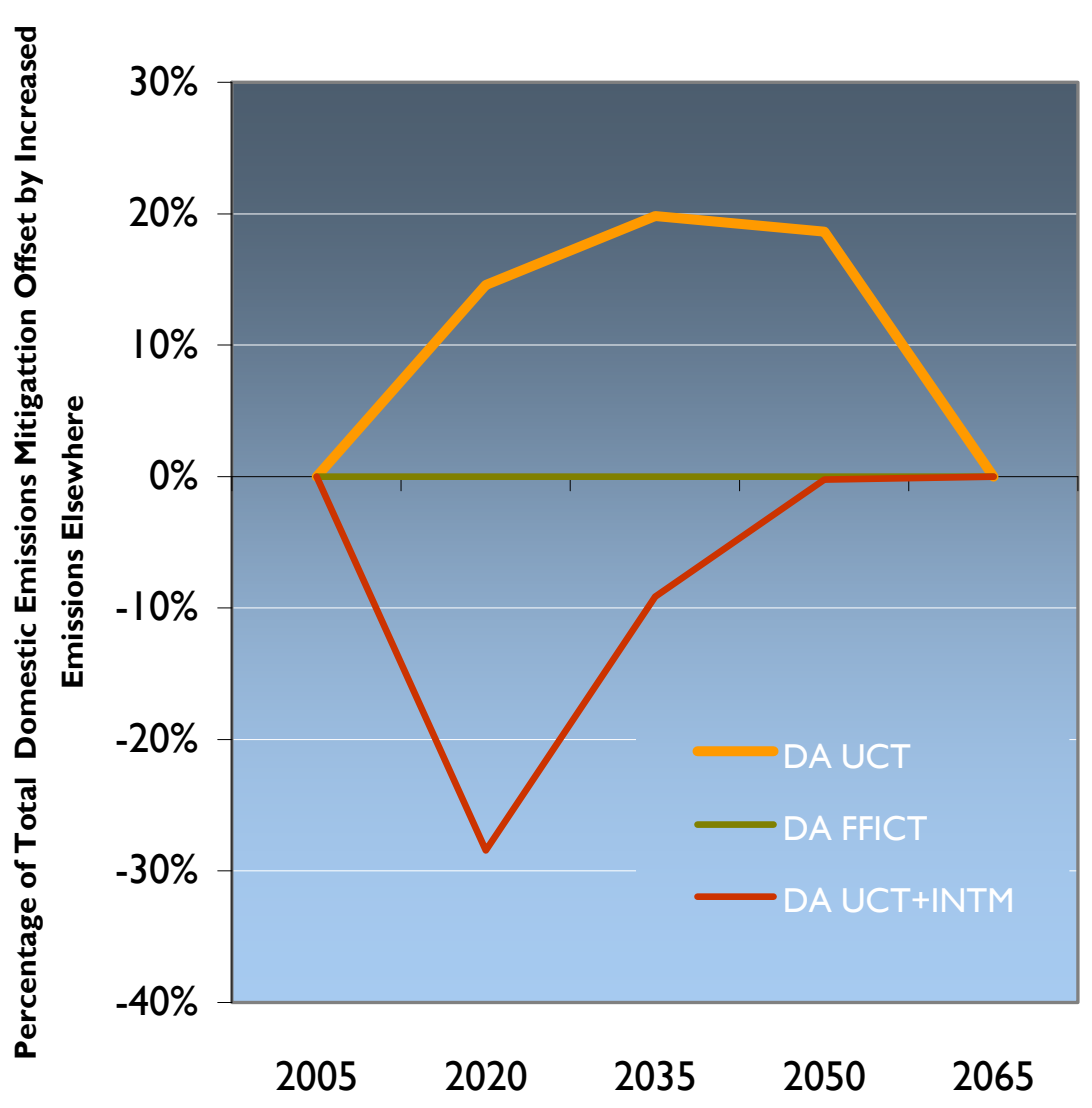


Figure 7: Land Use in the DA_UCT Scenario by Group, 2005 to 2095

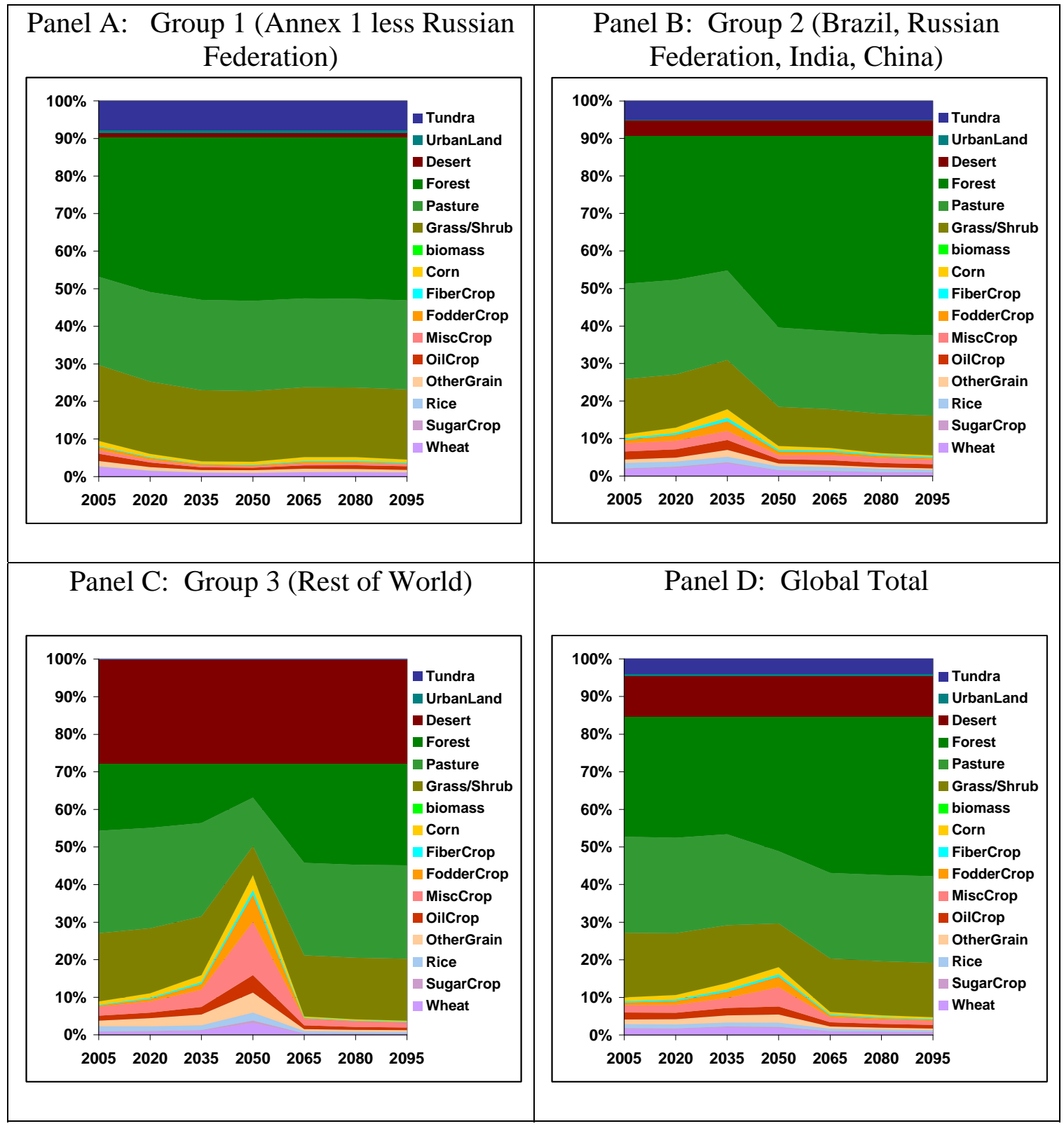


Figure 8: Land Use in the Reference Scenario by Group, 2005 to 2095

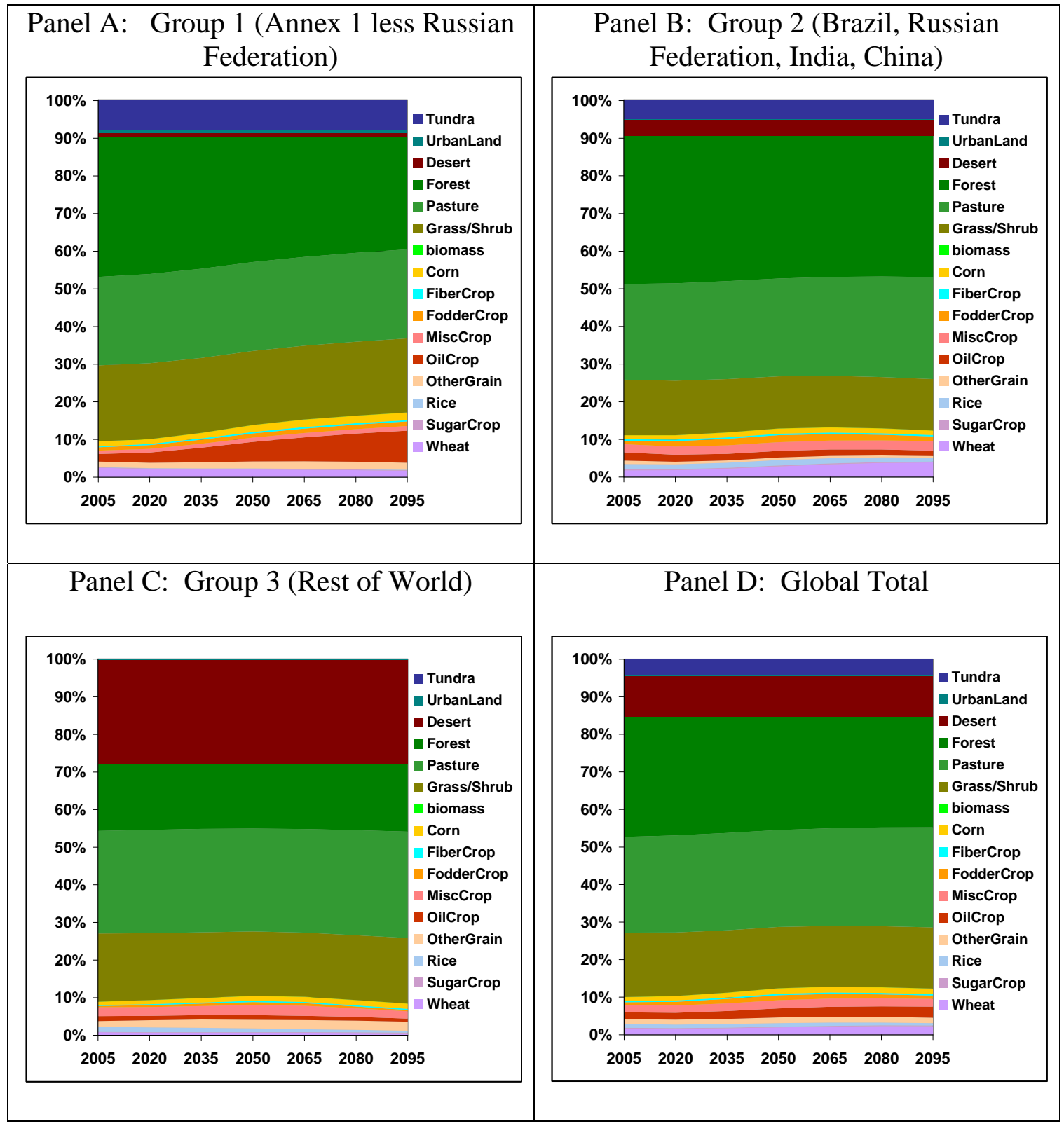


Figure 9: Land Use in the Immediate Accession with a Universal Carbon Tax, IA_UCT Scenario by Group, 2005 to 2095

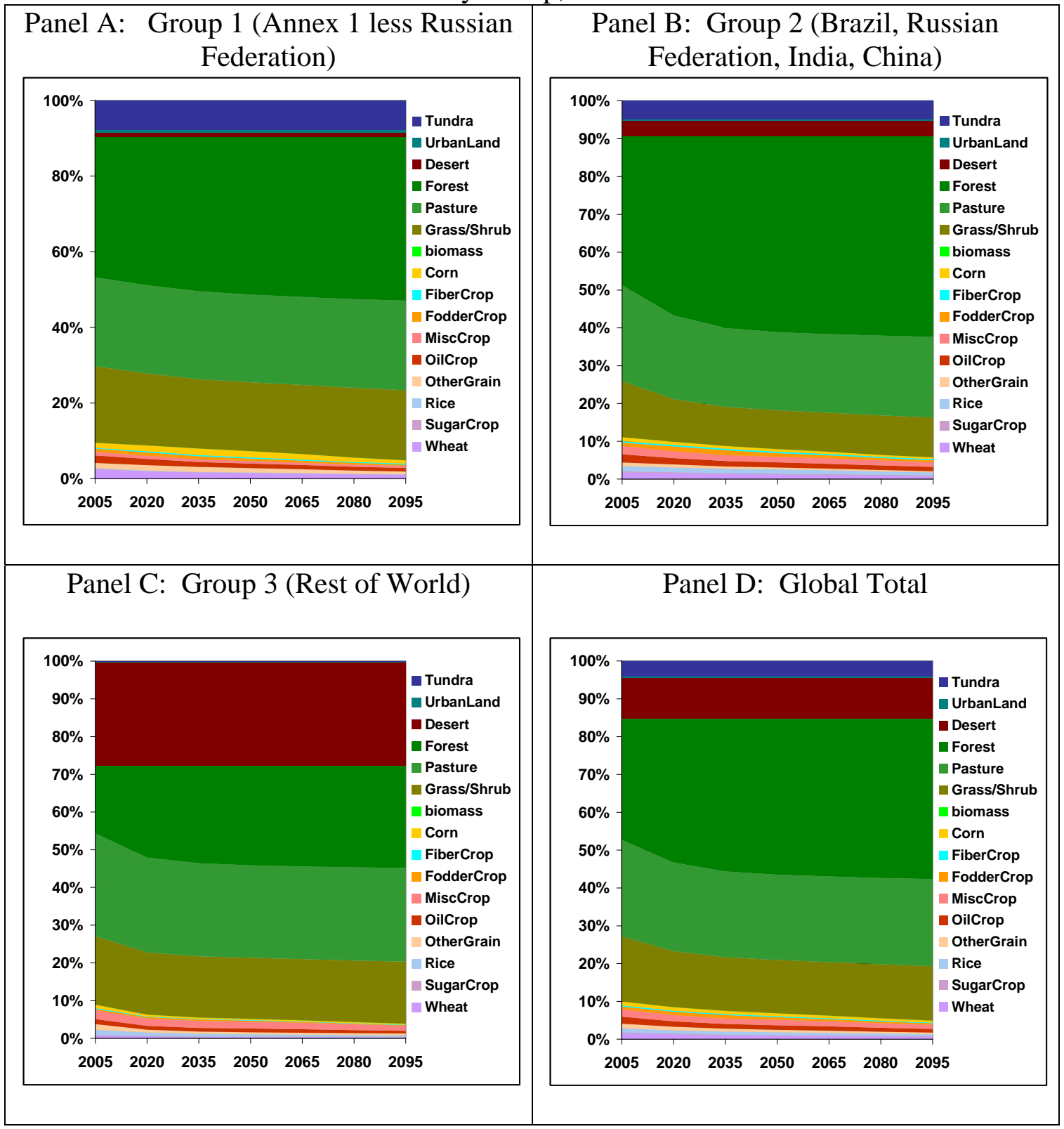


Figure 10: $\quad$ Total Land-use Leakage Associated with Land-use Policies (solid lines) and Bioenergy Production (dashed lines) from Coalition Regions, Measured as a Percentage of Total Anthropogenic Emissions Mitigations, 2005 to 2095

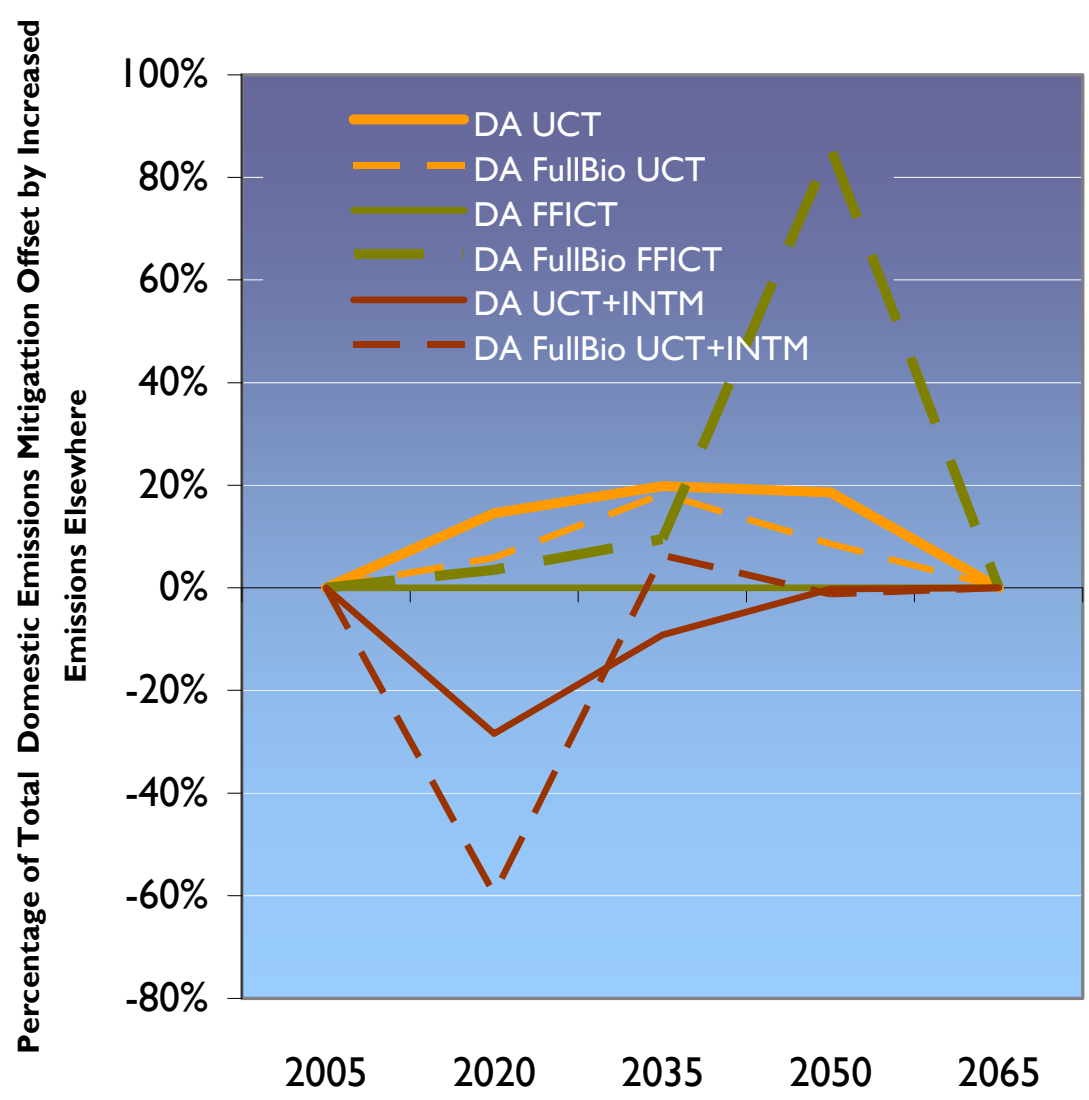

